\title{
Pelaksanaan Tugas Fungsi dan Kewenangan Kejaksaan Republik Indonesia dalam Hubungannya dengan Sistem Ketatanegaraan di Indonesia Menurut Undang Undang Nomor 16 Tahun 2004
}

\author{
Sanusi, Lorent Pradini Imso. \\ Universitas Pancasakti Tegal \\ Sanusi6362@gmail.com lorentimso@gmail.com
}

\begin{abstract}
Prosecutors are government officials in the field of law, in charge of submitting charges or allegations in court proceedings against suspected unlawful persons. In Dutch it is called Officer Van Justitie, in English called Public prosecutor. Prosecutors as one of the law enforcement has a responsibility to run a legal development strategy that has been secured in law. Law No. 16 of 2004 concerning the Attorney General of Indonesia has ensured the independence of prosecutors in carrying out its duties, as stated in article 2 paragraph (2). However, in the next provisions the position of prosecutors can not be separated from the executive institutions. So that in the execution of his duties prosecutors often faced with the problem of self-reliance on the achievement of tasks, because however the prosecutor can not escape the shadows of the executive institutions, this is what causes prosecutors Often considered unprofessional. Avoiding the president's single domination in determining the office of the Attorney general, it must be done by involving other institutions such as the House of Representatives for the approval of all people. Realizing that the prosecution's power is part of the judicial power, the sense of judicial power outlined in the CONSTITUTION 1945 the amendment will need to be reviewed again. Alignment in judicial power can give influence and control to one another. Therefore, it is necessary to put the power of investigation and prosecution in the chapter of judicial authority in the CONSTITUTION 1945 when later the Fifth Amendment.
\end{abstract}

Keyword: Attorney, Attorney's job, prosecutor's office, attorney's Office, constitutional system

\begin{abstract}
Abstrak
Jaksa adalah pegawai pemerintah yang berkecimpung di bidang hukum, bertugas menyampaikan dakwaan atau tuduhan didalam proses pengadilan terhadap orang yang diduga melanggar hukum. Dalam bahasa Belanda disebut officer van justitie, dalam bahasa inggris disebut public prosecutor. jaksa sebagai salah satu penegak hukum mempunyai tanggungjawab untuk menjalankan strategi pembangunan hukum yang telah dijamin dalam undang- undang. Undang Undang Nomor 16 Tahun 2004 tentang Kejaksaan Republik Indonesia telah menjamin kemandirian kejaksaan dalam melaksanakan tugasnya, sesuai yang tercantum dalam pasal 2 ayat (2). Akan tetapi dalam ketentuan selanjutnya kedudukan kejaksaan tidak dapat terlepas dari lembaga eksekutif. Sehingga dalam pelaksanaan tugasnya kejaksaan seringkali dihadapkan pada persoalan kemandirian dalm pencapaian tugas, karena bagaimanapun kejaksaan tidak dapat melepaskan diri dari bayangbayang lembaga eksekutif, hal inilah yang menyebabkan kejaksaan sering dianggap tidak profesional. Menghindari dominasi tunggal Presiden dalam menentukan jabatan Jaksa Agung, maka harus dilakukan dengan melibatkan lembaga lain seperti DPR atas persetujuan dari seluruh rakyat. Menyadari bahwa kekuasaan penuntutan merupakan bagian dari kekuasaan kehakiman, maka pengertian kekuasaan kehakiman yang dijabarkan dalam UUD 1945 hasil amandemen perlu ditinjau kembali. Keterpaduan dalam kekuasaan kehakiman dapat memberikan pengaruh dan kontrol satu sama lain. Maka dari itu sangat diperlukan untuk meletakkan kekuasaan penyelidikan dan
\end{abstract}


penuntutan dalam bab kekuasaan kehakiman didalam UUD 1945 apabila di kemudian hari dilakukan amandemen kelima.

Keyword: Kejaksaan, Tugas Kejaksaan, Fungsi Kejaksaan, Kewenangan Kejaksaan, Sistem Ketatanegaraan

\section{A. Pendahuluan}

Penegakan supremasi hukum mengandung makna bahwa semua pihak baik warga masyarakat dan penyelenggara negara, penyelenggara lembaga negara, dan badan-badan kekuasaan negara wajib mematuhi hukum. Hal ini menjadikan asas bersama kedudukan di hadapan hukm benar-benar direalisasikan bukan hanya berupa motto atau slogan belaka.Bersama dengan kedudukan hukum dihadapan hukum berarti penegakan hukum terlaksana tanpa memihak, terlepas dari pengaruh-pengaruh pihak manapun dan untuk itu maka aparat penegak hukum harus bebas dari segala pengaruh.

Dengan berlandaskan spirit Amandemen UUD 1945 yang mempertegas fungsi dan kewenangan untuk setiap cabang kekuasaan baik Eksekutif, Legislatif, dan Yudikatif. Maka dibutuhkan sebuah reposisi atau penempatan kembali lembaga-lembaga negara termasuk didalamnya lembaga penegak hukum untuk dikambalikan kepada peran dan fungsinya yang murni yaitu menegakkan hukum dan keadilan secara mandiri dan bebas tanpa campur tangan pihak manapun.

Jaksa adalah pegawai pemerintah yang berkecimpung di bidang hukum, bertugas menyampaikan dakwaan atau tuduhan didalam proses pengadilan terhadap orang yang diduga melanggar hukum. Dalam bahasa Belanda disebut officer van justitie, dalam bahasa inggris disebut public prosecutor. ${ }^{1}$ jaksa sebagai salah satu penegak hukum mempunyai tanggungjawab untuk menjalankan strategi pembangunan hukum yang telah dijamin dalam undang- undang.

\footnotetext{
1 Sudarsono, Kamus Hukum, Jakarta: Reneka Cipta, 1992, hlm. 191.
} 
Undang Undang Nomor 16 Tahun 2004 tentang Kejaksaan Republik Indonesia telah menjamin kemandirian kejaksaan dalam melaksanakan tugasnya, sesuai yang tercantum dalam pasal 2 ayat (2). Akan tetapi dalam ketentuan selanjutnya kedudukan kejaksaan tidak dapat terlepas dari lembaga eksekutif. Sehingga dalam pelaksanaan tugasnya kejaksaan seringkali dihadapkan pada persoalan kemandirian dalm pencapaian tugas, karena bagaimanapun kejaksaan tidak dapat melepaskan diri dari bayang-bayang lembaga eksekutif, hal inilah yang menyebabkan kejaksaan sering dianggap tidak profesional.

Disamping masalah kemandirian, kejaksaan juga tidak terlepas dari isu mafia peradilan, bahkan kejaksaan dapat menjadi promotor dari tindakan penyelewengan peradilan, selain itu kejaksaan juga berhadapan dengan ancaman terhadap dirinya sendiri atau bahkan keluarganya sekalipun ketika menangani kasus-kasus tertentu. Melihat realitas yang demikian, disalah satu sisi kejaksaan sebagai aparat penegak hukum yang harus profesional dan mandiri dalam usahanya menjaga supremacy of law, namun fungsi dan kedudukan jaksa yang berada di bawah eksekutif membuat jaksa harus berada dalam keadaan dilematis untuk menegakkan hukum.

\section{B. Negara Hukum}

Negara maupun perseorangan adalah subjek-subjek hukum, yang harus memandang sebagai sesamanya, yaitu sebagai pihakpihak yang sama dalam memegang hak-hak dan kewajiban. Hal ini mempunyai arti bahwa negar tidak dapat memandang perseorangan sebagai objek yang tidak bernyawa dan tidak mempunyai hak atas berbagai hal. Agar tercapainnya cita-cita ini, maka menurut Imanuel Kant negara harus mengadakan pembagian kekuasaan sesuai 
dengan ajaran Trias Politica. ${ }^{2}$ Ada tiga prinsip yang harus dipenuhi di dalam negara hukum, antara lain sebagai berikut:

1. Supremasi hukum (Supremacy of Law) yang berarti bahwa semua pihak dalam masyarakat atau negara, baik warga atau pemegang kekuasaan wajib tunduk terhadap hukum.

2. Persamaan kedudukan semua pihak terhadap hukum (Equality before the Law) yang berarti bahwa setiap komponen dalam masyarakat atau negara, baik individu, kelompok, maupun pemegang kekuasaan sama kedudukannya terhadap hukum.

3. Benar tepatnya proses pembentukan dan pelaksanaan hukum (Due Process of Law) yang berarti bahwa cara dan mekanisme yang ditempuh dalam pembentukan hukum dan dalam menjalankannya harus tapat dan benar, sebagaimana yang telah ditetapkan oleh peraturan yang telah disepakati dan disahkan. ${ }^{3}$ Dalam perkembangannya negara hukum mempunyai konsep yang berbeda-beda dalam melindungi kesejahteraan warganya. Pada abad 19 di Eropa timbul gagasan konstitualisme dalam sistem ketatanegaran. Dimana ciri penting dalam negara yang menganut konstitualisme (demokrasi konstitusional) bahwa sifat pemerintah yang pasif artinya pemerintah hanya menjadi wasit rakyat di Parlemen. ${ }^{4}$

Pemisahan kekuasaan dalam perkembangannya telah berubah menjadi pembagian kekuasaan. Persoalan negara hukum bukan mengenai ada tidaknya trias politica akan tetapi persoalannya terletak pada alat-alat kekuasaan negara yang harus terhindar dari praktik-praktik birokrasi dan tirani. Dan hal ini tidak

\footnotetext{
2 Sudargo, Gautama, Pengertian Tentang Negara Hukum, Bandung: Alumni, 2001, hlm. 5.

3 Hatono Mardjono, Negara Hukum yang Demokratis sebagai Landasan MembangunIndonesia Baru, Koridor Pengabdian, Jakarta: 2001, hlm. 15.

${ }^{4}$ Moh. Mahfud MD, Demokrasi dan Konstitusi di Indonesia, Jakarta: Rineka Cipta, 2003, hlm. 26.
} 
bergantung pada pemisahan kekuasaan itu sendiri melainkan bergantung pada sendi negara demokrasi yaitu berupa kedaulatan rakyat. ${ }^{5}$

Indonesia sejak reformasi 1998 telah membawa perubahan besar dalam sistem ketatanegaraan Indonesia.Dimana sebelumnya kekuasaan eksekutif memegang peranan yang sangat penting, hal inilah yang menyebabkan banyak kalangan berpendapat bahwa konstitusi Indonesia yaitu UUD 1945 banyak mengandung sutu kelemahan. Tidak terdapatnya prinsip checks and balance yang memadai (executive heavy), sehingga menyebabkan jabatan sebagai presiden sangat menguntungkan. Menurut Soepomo keadaan yang demikian sering disebut "concentration of power and responsibility upon the president". ${ }^{6}$

C. Pelaksanaan Tugas, Fungsi dan Keewenangan Kejaksaan dalam Sistem Ketatanegaraan di Indonesia Menurut UU Nomor 16 Tahun 2004.

Di dalam UU No. 16 Tahun 2004 tentang Kejaksaan Republik Indonesia pasal 30 ayat (2) menyebutkan bahwa “Di bidang perdata dan tata usaha negara, Kejaksaan dengan kuasa khusus dapat bertindak didalam maupun diluar [pengadilan untuk dan atas nama negara atau pemerintah". Berdasarkan Staatsblad No 522 Tahun 1922, Kejaksaan diberi tugas dan fungsi di bidang hukum perdata. Selain itu di dalam KUHPerdata (Burgerlijke Wetboek) telah tercantum ketentuan mengenai tugas dan wewenang Kejaksaan dalam bidang keperdataan, yaitu berupa wewenang Kejaksaan dalam pengajuan permohonan kepada Pengadilan untuk memerintahkan Balai Harta Peninggalan mengurus harta dan kepentingan orang yang meninggalkan tempat tinggalnya tanpa memberitahukan tempat tinggal yang baru dan tanpa kabar berita (pasal 463 KUHPerdata).

Secara berkesinambungan tugas dan fungsi Kejaksaan pada bidang keperdataan ini diatur di dalam UU No 15 Tahun 1961 tentang Kejaksaan

\footnotetext{
${ }^{5}$ Ismail Suny, Mencari Keadilan, Bandung: Ghalia Indah, 1982, Hlm. 16.

${ }^{6}$ Nimatul Huda, Diktat bahan kuliah Hukum Tata Negara Indonesia, Yogyakarta: FH UII, 2005, hlm. 72.
} 
Republik Indonesia pada pasal 2 ayat (4) dinyatakan bahwa Kejaksaan mempunyai tugas khusus lain yang diiberikan oleh suatu peraturan negara. Di dalam UU No 5 Tahun 1991 tentang Kejaksaan untuk turut serta menjaga dan menegakkan kewibawaan pemerintah dan negara serta melindungi kepentingan rakyat melalui penegakkan hukum. Tugas, fungsi dan wewenang Kejaksaan dalam bidang perdata dan tata usaha negara dilakukan oleh Jaksa Agung Muda bidang Perdata dan Tata Usaha Negara. Secara garis besar tugas Kejaksaan dalam bidang hukum perdata dan tata usaha negara dapat dibedakan menjadi lima kelompok, yaitu:

1. Penegakkan Hukum

2. Bantuan Hukum

3. Pertimbangan Hukum

4. Pelayanan Hukum

5. Tindakan Hukum Lain

Fungsi eksternal Kejaksaan di bidang hukum perdata dan hukum tata negara berkaitan dengan tugas dan wewenang penegakkan hukum, bantuan hukum, pertimbangan hukum, pelayanan hukum serta tindakan hukum lainnya, Kejaksaan mempunyai fungsi antara lain, sebagai berikut:

a. Membatalkan suatu perkawinan yang dilakukan dimuka pencatatan sipil yang tidak berwenang, wali nikah yang tidak sah atau tanpa dihadiri oleh dua orang saksi. (UU No 1 Tahun 1974)

b. Meminta Pengadilan untuk menyatakan suatu keadaan pailit terhadap perseorangan atau badan hukum demi kepentingan umum.

c. Melakukan gugatan pembayaran uang pengganti atas putusan Pengadilan yang telah mempunyai kekuatan hukum tetap dalam perkara tindak pidana korupsi. 
d. Melakukan gugatan ganti kerugian, biaya pemilihan serta tindakan hukum lainnya yang timbul dari perbuatan melawan hukum yang menimbulkan kerugian negara atau kekayaan negara.

e. Melakukan somasi, negosiasi, mediasi dan tindakan hukum lain didalam mewakili kepentingan negara, pemerintah atau masyarakat.

f. Pembinaan kerjasama, pelaksanaan koordinasi, pemberian saran pertimbangan, bimbingan serta petunjuk tekhnis dalam penanganan perkara perdata dan tata usaha negara dengan instansi terkait di pusat maupun di daerah berdasarkan peraturan perundang-undangan dan kebijaksanaan yang ditetapkan oleh Jaksa Agung.

g. Membina kerjasama, melakukan konsultasi, koordinasi, memberikan pelayanan dan pertimbangan dibidang perdata dan tata usaha negara serta memberikan bimbingan dan petunjuk tekhnis dalam penanganan perkara kepada instansi lain.

h. Pemberian bantuan dan pelayanan hukum kepada lembaga negara dan instansi pemerintah baik sebagai penggugat maupun tergugat di pengadilan perdata dan sebagai tergugat dalam pengadilan tata usaha negara.

i. Menerima, mengolah dan menelaah laporan, pengaduan atau informasi dalam rangka penegakan, bantuan, pertimbangan dan pelayanan hukum kepada instansi lain atau masyarakat.

j. Pelaksanaan tindakan hukum di dalam maupun di luar pengadilan,mewakili kepentingan keperdataan dari negara, pemerintah dan masyarakat baik berdasarkan jabatan maupun kuasa khusus di dalam atau di luar negeri.

Dalam melaksanakan fungsi ekternal tertentu, Kejaksaan mempunyai landasan hukum, yaitu: 
a. Karena jabatan, Peranan Kejaksaan dalam perkara perdata ada yang dibetikan oleh perundang-undangan dan bersifat atributif, misalnya dalam membatalkan suatu perkawinan.

b. Kuasa khusus, Kejaksaan dapat bertindak mewakili negara, pemerintah, badan usaha milik negara, badan tata usaha negara dan pejabat tata usahaa negara dalam perkara perdata dan tata usaha negara, karena adanya kuasa khusus. Dimana mereka berhak menunjuk pihak lain selain kejaksaan untuk mewakili dan mengurus kepentingan tersebut.

c. Mewakili kepentingan umum, Keppres No 86 Tahun 1999 pasal 21 huruf f, menyatakan bahwa Kejaksaan mempunyai fungsi pelaksanaan tindakan hukum di dalam atau di luar pengadilan "mewakili kepentingan keperdataan dari Negara atau pemerintah dan masyarakat berdasarkan jabatan maupun kuasa khusus". Di dalam Keputusan Jaksa Agung Nomor: KEP-115/JA/10/1999 pasal 348 huruf d dinyatakan bahwa melaksanakan tindakan hukum untuk mewakili kepentingan masyarakat dalam rangka pemulihan dan perlindungan hak keperdataan, sehubungan dengan pemberian hak cipta, hak paten, hak merek, hak peruntukan tanah, hak pengusahaan hutan dan hak-hak keperdataan lainnya".

Fungsi internal bersifat managerial, sebagai upaya agar tugas dan wewenang Kejaksaan dapat dilaksanakan secara optimal. Fungsi tersebut, antara lain:

a. Perumusan kebijaksanaan tekhnis kegiatan yustisial perdata dan tata usaha negara berupa pemberian bimbingan dan pembinaan dalam bidang tugasnya.

b. Perencanaan, pelaksanaan dan pengendalian kegiatan, pelaksanaan, bantuan, pertimbangan dan pelayanan hukum, pelaksanaan gugatan uang pengganti atas putusan pengadilan, gugatan ganti kerugian dan tindakan 
hukum lain terhadap perbuatan yang merugikan keuangan negara, mewakili dan membela kepentingan negara dan pemerintah serta pengadministrasiannya.

c. Penerima, mengolah dan menelaah laporan, pengaduan atau informasi dalam rangka penegakan, bantuan, pertimbangan dan pelayanan hukum kepada instansi lain atau masyarakat.

d. Pembinaan kerjasama dengan instansi terkait dan aparatur penyidik serta penuntut umum dalam penanganan perkara yang menimbulkan kerugian keuangan atau perekonomian negara.

e. Pemberian saran, konsepsi tentang pendapat dan pertimbangan hukum Jaksa Agung mengenai perkara perdata dan tata usaha negara serta masalah hukum lainnya dalam kebijaksanaan penegakkan hukum.

f. Pembinaan dan peningkatan kemampuan, keterampilan dan integritas kepribadian aparat perdata dan tata usaha negara di lingkungan Kejaksaan.

Tujuan dari Kejaksaan yaitu, antara lain sebagai berikut:

a. Menjamin tegaknya hukum.

b. Melindungi kepentingan umum.

c. Menyelamatkan kekayaan negara.

d. Menegakkan kewibawaan pemerintah.

\section{Fungsi, Tugas dan Wewenang Kejaksaan dalam Bidang Ketertiban dan}

\section{Ketenteraman Umum}

Dalam bidang ketertiban dan ketenteraman umum (intelijen), kejaksaan ikut andil dalam penyelenggaraan suatu kegiatan berupa, antara lain sebagai berikut:

a. Pengamanan kebijakan penegakan hukum.

b. Peningkatan kesadaran hukum masyarakat yang dilakukan dengan program jaksa masuk desa yang bertujuan untuk menumbuhkan dan membina serta meningkatkan kesadaran hukum masyarakat, terutama pada masyarakat 
pedesaan yang awam dan buta hukum, dengan cara diselenggarakannya kegiatan penyuluhan hukum oleh para jaksa dengan sistem pendekatan secara langsung.

c. Pengawasan aliran kepercayaan yang dapat membahayakan masyarakat dan negara.

d. Pengawasan peredaran barang cetakan.

e. Pencegahan penyalahgunaan dan atau penodaan agama.

f. Penelitian dan pengembangan hukum serta statistik kriminal.

Tugas dan wewenang kejaksaan dalam bidang ketertiban dan ketenteraman umum serta tugas umum pemerintah dan pembangunan di bidang hukum seharusnya bersifat preventif dan edukatif. Akan tetapi tugas dan wewenang kejaksaan di bidang intelijen ini perlu ditinjau kembali karena nilai-nilai yang terkandung didalam aturan tersebut tidak sesuai dengan perkembangan bangsa Indonesia saat ini.Dimana pada saat ini bangsa Indonesia snagat mengedepankan nilai-nilai kebebasan bagi warga negaranya untuk mengaktualisasikan dan mengekspresikan diri dalam kehidupan sosial dan bermasyarakat.

Tugas dan wewenang jaksa untuk menciptakan ketertiban dan ketenteraman masyarakat jelas sangat keliru, dimana tugas dan wewenang tersebut seharusnya merupakan tugas utama dari Kepolisian dan bukan merupakan tugas dan wewenang dari Kejaksaan.

\section{E. Kedudukan Kejaksaan dalam Sistem Ketatanegaraan di Indonesia}

Sebelum mengetahui kedudukan Kejaksaan Republik Indonesia dalam sistem ketatanegaraan di Indonesia, maka diharuskan terlebih dahulu untuk mengetahui sistem hukum yang ada di Indonesia terutama mengenai sistem ketatanegaraan Indonesia. Menurut DR. Zainal dalam bukunya Pengantar Tata Hukum Indonesia, sistem adalah tatanan atau kesatuan yang utuh yang terdiri 
dari bagian-bagian atau unsur-unsur yang berkaitan erat satu sama lain yaitu mengenai kaidah dan pernyataan tentang apa yang seharusnya.

Menurut Schrode dan Voich pemahaman yang umum mengenai sistem adalah suatu kesatuan yang bersifat kompleks, yang terdiri dari bagian-bagian yang berhubungan satu sama lain. Pemahaman yang demikian itu hanya menekankan pada ciri keterhubungan dari bagian-bagiannya dengan mengabaikan ciri-ciri yang lain. Yaitu bahwa bagian-bagian tersebut bekerja bersama secara aktif untuk mencapai tujuan pokok dari kesatuan tersebut. Apabila suatu sistem itu ditempatkan pada pusat pengamatan yang demikian, maka pengertian-pengertian dasar yang terkandung di dalamnya adalah sebagai berikut:

a. Sistem berorientasi kepada tujuan.

b. Keseluruhannya adalah lebih dari sekedar jumlah dari bagianbagiannya (Wholism).

c. Suatu sistem berinteraksi dengan sistem yang lebih besar, yaitu lingkungannya (keterbukaan sistem).

d. Bekerjanya bagian-bagian dari sistem itu menciptakan sesuatu yang berharga (transformasi).

e. Masing-masing bagian harus cocok satu sama lain (keterhubungan).

f. Ada kekuatan pemersatu yang mengikat sistem itu (mekanisme kontrol).

Menurut J.B. Daliyo sistem hukum adalah kesatuan utuh dari tatanantatanan yang terdiri dari bagian-bagian atau unsur-unsur yang satu sama lain aling berhubungan dan berkaitan secara erat. Untuk mencapai suatu tujuan kesatuan tersebut perlu kerjasama antar bagian-bagian atau unsur-unsur tersebut menurut rencana dan pola tertentu.Hukum yang merupakan sistem tersusun atas sejumlah bagian yang masing-masing merupakan sistem yang dinamakan subsistem. 
Kejaksaan merupakan bagian dari sistem hukum Indonesia khususnya menyangkut penegakan hukum.Jaksa adalah salah satu dari aparat penegak hukum selain hakim, polisi dan advokat.Kedudukan kejaksaan dalam sistem ketatanegaraan dapat dijelaskan dengan penjelasan mengenai pengertian dari hukum tata negara.

Menurut Kusumadi Pudjosewono bahwa hukum tata negara adalah hukum yang mengatur bentuk negara, bentuk pemerintahan, yang menunjukkan hukum atasan dan masyarakat sebagai hukum bawahan menurut tingkatanya.Selanjutnya menegaskan wilayah lingkungan rakyatnya msingmasing mengenai masyarakat hukum, menunjukkan alat-alat perlengkapan negara yang berkuasa dalam masing-masing masyarakat hukum serta susunan, wewenang dan imbangan dari alat perlengkapan tersebut.

Sistem ketatanegaraan adalah satu kesatuan hukum yang mengatur organisasi negara dan susunan (struktur) umum negara yang terdapat dalam undang-undang dasar dan peraturan pelaksanaannya yang terdiri atas bagianbagian, seperti substansi hukum, struktur hukum, dan budaya hukum yang mempunyai kaitan satu sama lain, tersusun secara tertib dan teratur menurut asas-asasnya, yang berfungsi untuk mencapai suatu tujuan dari sistem hukum tersebut.

Sistem ketatanegaraan suatu negara terdapat dalam konstitusi dan peraturan perundang-undangan dibawahnya, termasuk sistem ketatanegaraan Indonesia diatur dalam Undang-Undang Dasar 1945 dan peraturan-peraturan perundang-undangan dibawahnya sebagai peraturan pelaksanaannya. Menurut E.C.S. Wade UUD adalah naskah yang memaparkan rangka dan tugas-tugas pokok dari badanbadan pemerintahan suatu negara dan menentukan pokok cara kerja dari badan-badan tersebut. UUD 1945 memuat ketentuan-ketentuan mengenai, antara lain sebagai berikut: 
a. Organisasi negara, yaitu mengenai pembagian kekuasaan dari legislatif, eksekutif dan yudikatif.

b. Hak asasi manusia.

c. Prosedur mengubah Undang-Undang Dasar.

d. Memuat larangan-larangan untuk mengubah sifat tertentu dari UUD.

UUD 1945 tidak menyebutkan sepatah katapun mengenai Kejaksaan. Terdapat tiga pasal dalam UUD 1945 yang sekalipun dengan tidak tegas dan eksplisit mengatur eksistensi Kejaksaan beserta tugas dan wewenangnya, akan tetapi dapat ditafsirkan secara historis bahwa para perancangnya telah mengetahui dan menyadari adanya Kejaksaan yang pada saat itu menjadi satu dengan Kehakiman yaitu pada pasal 24 UUD 1945yang berbunyi Kekuasaan Kehakiman dilakukan oleh sebuah Mahkamah Agung dan lain-lain Badan Kehakiman menurut Undang-Undang. Pada pasal 25 UUD 1945 yang berbunyi Syarat-syarat untuk menjadi dan untuk diberhentikkan sebagai hakim ditetapkan dengan undang-undang.

Sebelum Indonesia merdeka, pemerintah militer Jepang menggunakan istilah disamping Mahkamah Agung ada Kejaksaan Agung begitu pula pada pengadilan-pengadilan dibawahnya. Pada sidang PPKI tanggal 19 Agustus 1945 dengan agenda memusyawarahkan pembentukan departemen-departemen, ada sebanyak lima kali kata Kejaksaan disebutkan. Lalu diputuskan bahwa Kejaksaan dimasukkan ke dalam lingkungan Departemen Kehakiman.

Sampai terjadinya reformasi dan diikuti dengan dilakukanya empat kali amandemen terhadap UUD 1945 kata Kejaksaan tidak juga tercantum dalam UUD 1945 pasca amandemen.Tidak seperti halnya aparat penegak hukum lainnya baik hakim dan juga polisi yang kedudukannya dijamin dalam UUD 1945 pasca amandemen. Akan tetapi pada pasal 24 ayat (3) yang dipertegas pada pasal 41 UU No 4 Tahun 2004tentang kekuasaan kehakiman yang menjelaskan bahwa 
badan-badan lain yang fungsinya berkaitan dengan kekuasaan kehakiman meliputi Kepolisian Negara Republik Indonesia, Kejaksaan Republik Indonesia, dan badan-badan lain diatur dalam undang-undang.

Pada pasal 2 ayat (1) UU No 16 Tahun 2004 tentang Kejaksaan RI menyebutkan bahwa Kejaksaan Republik Indonesia yang selanjutnya disebut kejaksaan adalah lembaga pemerintahan yang melaksanakan kekuasaan negara dibidang penuntutan serta kewenangan lain berdasarkan undang-undang. Dengan demikian, kejaksaan berkedudukan sebagai bagian dari kekuasaan pemerintah dbawah presiden.

Kejaksaan dipimpin oleh seorang Jaksa Agung yang pengangkatannya merupakan hak dari Presiden.Dalam pasal 19 ayat (1) disebutkan bahwa Jaksa Agung adalah pejabat negara, sedangkan ayat (2) Jaksa Agung diangkat dan diberhentikan oleh Presiden.Pelaksanaan kekuasaan negara dalam bidang penuntutan ini diselenggarakan oleh Kejaksaan Agung, Kejaksaan Tinggi, dan Kejaksan Negeri. Kejaksaan Agung berkedudukan di Jakarta dan daerah hukumnya meliputi wilayah kekuasaan negara Republik Indonesia.Kejaksaan tinggi berkedudukan di ibukota provinsi dan daerah hukumnya meliputi wilayah provinsi.Sedangkan Kejaksaan Negeri berkedudukan di ibukota kabupaten/kota yang daerah hukumnya meliputi daerah kabupaten/kota.

Dalam perspektif profesionalitas dan kemandirian aparat Kejaksaan, kedudukan seperti ini sangatlah tidak menguntungkan, sebab kecenderungan munculnya intervensi dari kekuasaan pemerintah sangat tinggi. Secara struktural, campurtangan yang demikian mungkin dapat dibenarkan, akan tetapi jika hal tersebut menyangkut kepentingan rakyat banyak, campur tangan kekuasaan pemerintah menjadi sesuatu yang tidak bijaksana.

\section{F. Kemandirian Kejaksaan Republik Indonesia}


Di dalam penelitian mengenai kemandirian suatu lembaga negara, maka kita diharuskan untuk membedakannya menjadi dua bagian yaitu kemandirian secara struktural (kelembagaan) dan kemandirian secara fungsional. Kemandirian struktural adalah kemandirian yang berkaitan dengan lembaga itu sendiri, apakah lembaga tersebut memiliki ketergantungan dengan lembaga lain atau tidak, kemudian apakah lembaga tersebut mempunyai hubungan yang hierarkis keatas secara formal dimana lembaga atasannya tersebut dapat mempengaruhi kemandirian terhadap lembaga tersebut. Sedangkan kemandirian fungsional adalah kemandirian sebuah lembaga atau instansi atau dalam hal ini Jaksa dalam menjalankan tugas, fungsi dan kewenangannya.

\section{(a) Kemandirian Kelembagaan Kejaksaan Republik Indonesia}

Pada konteks ilmu manajemen pemerintahan, Jaksa Agung sebagai bawahan Presiden, harus mampu melakukan tiga hal, yaitu: pertama, menjabarkan instruksi, petunjuk dan berbagai bentuk kebijakan lainnya dari Presiden dalam tugas dan wewenangnya dalam bidang penegakkan hukum; kedua, melaksanakan instruksi, petunjuk dan berbagai bentuk kebijakan lainnya dari Presiden yang telah dijabarkan tersebut; ketiga, mengamankan instruksi, petunjuk dan berbagai bentuk kebijakan lainnya dari Presiden yang sementara dan telah dilaksanakan.

Dedikasi, loyalitas dan kredibilitas Jaksa Agung dihadapan Presiden diukur sejauh mana Jaksa Agung mampu melaksanakan ketiga hal tersebut. Dedikasi, loyalitas dan kredibilitas Jaksa Aung sebagai pengemban kekuasan negara dalam bidang penegakan hukum, akan tetapi disinilah letak ketidak mandirian dari Lembaga Kejaksaan di dalam mengemban kekuasaan negara dalam bidang penegakkan hukum.

Menurut Rony Rahman N. Bahwa sangat sulit bagi Kejaksaan untuk tidak terikat dengan politik dan kebijakan pemerintah.Jaksa tidak dapat dengan 
dalih demi profesi menentukan arah penuntutannya sendiri.Jaksa Agung sebagai bawahan Presiden harus tunduk dengan kebijakan hukum atasannya.Jadi, disinilah terdapat ambiguitas, Kejaksan yang merupakan lembaga pemerintah harus tunduk dan taat kepada perintah presiden karena secara hierarkis Kejaksaan merupakan lembaga pemerintahan yang pimpinannya diangkat oleh Presiden.Jika melihat fungsi, tugas dan kewenanganya Kejaksaan adalah lembaga yudikatif yang seharusnya mandiri.

Mantan Jaksa Agung Ismail Saleh mengatakan bahwa dalam kenyataannya campur tangan, intervensi atau pengaruh baik langsung atau tidak langsung dari Presiden dan eksekutif sulit untuk dihindari. Namun demikian, tergantung dari diri kita sendiri apa mau atau tidak untuk diintervensi. Intervensi bisa dalam bentuk pengaruh atau kekuasaan dari para pemegang keuasaan di pemerintahan, hal itu dipertegasnya dengan pernyataan bahwa selama menjabat sebagai Jaksa Agung pada tahun 1981-1984, di mana pada saat itu Soeharto menduduki jabatan sebagai Presiden,bahwa Presiden Soeharto tidak pernah mencampuri urusan kejaksaan. Ismail Saleh merasa independensi dalam pelaksanaan tugasnya benar-benar terjadi.Dimana tidak pernah ada suatu perintah baik tertulis maupun lisan dari Presiden Soeharto, apalagi menelepon untuk menangkap atau memeriksa orang tertentu atau menanyakan penyelesaian suatu perkara tidak pernah terjadi.

Melihat kenyataan diatas, tidak selamanya lembaga Kejaksaan yang dalam kedudukannya dibawah eksekutif selalu terintervensi secara kelembagaan baik melalui pesan-pesan politik maupun seperti apa yang dialami oleh A. Soedjono A. yang dengan semangatnya untuk memberantas korupsi mengakibatkan dicopotnya jabatan Jaksa Agung dari dirinya karena tidak sejalan dengan kepentingan pemerintah saat itu.

(b) Kemandirian Fungsional Kejaksaan Republik Indonesia 
Kemandirian Kejaksaan secara fungsional dapat dijelaskan dengan melihat ketentuan yang terdapat dalam pasal 1 angka empat UU No 16 Tahun 2004 bahwa Jabatan Fungsional Jaksa merupakan jabatan yang bersifat keahlian tekhnis dalam organisasi kejaksaan yang karena fungsinya memungkinkan kelancaran pelaksanaan tugas kejaksaan. Dari pasal tersebut dapat diterangkan bahwa untuk menjalankan tugas Kejaksaan dibutuhkan seseorang yang memiliki jabatan tekhnis dan menduduki jabatan fungsional jaksa.Jadi, bukan dari seseorang atau badan yang tidak memiliki keahlian tekhnis.Jabatan fungsional ini bersifat absolut. Disinilah kemandirian yang hakiki Kejaksaan dalam menjalankan fungsinya.

Jaminan kemerdekaan bagi Kejaksaan dalam melaksanakan fungsi, tugas dan wewenangnya terdapat dalam pasal 2 ayat (2) UU No. 16 Tahun 2004 tentang Kejaksaan Republik Indonesia yang dilaksanakan secara merdeka. Yang dimaksud secara merdeka dalam ketentuan ini adalah dalam melaksanakan fungsi, tugas, dan wewenangnya terlepas dari pengaruh kekuasaan pemerintah dan pengaruh kekuasaan lainnya.

Pasal 2 ayat (3) UU No 16 Tahun 2004 dalam melaksanakan fungsi, tugas dan wewenangnya kejaksaan harus mengedepankan prinsip "Kejaksaan adalah satu dan tidak terpisah-pisahkan dalam melakukan tuntutan".Pasal 8 ayat (2) berbunyi bahwa dalam melaksanakan tugas dan wewenangnya, Jaksa bertindak untuk dan atas nama negara serta bertanggung jawab menurut hierarki. Ketentuan yang menyatakan jaksa adalah salah satu dan tidak terpisahkan serta bertanggungjawab menurut hierarki merupakan salah satu ciri serta merupakan asas kejaksaan yang dalam sistem Kontinental dan Anglo Saxon dikenal sebagai The principle of indivisibility atau indivisible whole.

Seorang penuntut umum yang duduk bersidang di pengadilan pada saat itu tengah mengemban tugas mengganti Jaksa Agung. Penuntut umum 
adalah living image, other half, perfect substitute, shadow, twin, second self dari Jaksa Agung. Hal ini di lingkungan Kejaksaan RI selalu diimplementasikan melalui berbagai laporan, ekspose perkara penting, serta rencana tuntutan. Dalam melaksanakan penyelidikan dan tindakan prapenuntutan perkara tertentu tim jaksa yang menangani dan penuntut umum senantiasa diwajibkan untuk gelar perkara atau ekspose, sementara jaksa yang bersidang sebelum melaksanakan tuntutan perkara wajib menyampaikan rencana tuntutan secara berjenjang kepada Jaksa Agung.

Kejaksaan dipimpin oleh seorang Jaksa Agung. Jaksa Agung memiliki kewenangan, yaitu:

a. Menetapkan serta mengendalikan kebijakan penegakan hukum dan keadilan dalam ruang lingkup tugas dan wewenang kejaksaan.

b. Mengefektifkan proses penegakan hukum yang diberikan oleh undangundang

c. Menegsampingkan perkara demi kepentingan umum.

d. Mengajukan kasasi demi kepentingan umum kepada Mahkamah Agung dalam perkara pidana, perdata, dan htata usaha negara.

e. Mengajukan pertimbangan teknis hukum kepada Mahkamah Agung dalam pemeriksaan kasasi perkara pidana.

f. Mencegah atau menangkal orang tertentu untuk masuk atau keluar wilayah NKRI karena keterlibatanya dalam perkara pidana sesuai dengan peraturan perundang-undangan.

Dalam menjalankan tugas dan wewenangannya Jaksa Agung dibantu oleh seorang Wakil Jaksa Agung dan beberapa orang Jaksa Agung Muda.Jaksa Agung dan Wakil Jaksa Agung merupakan satu kesatuan unsur pimpinan.Jaksa Agung Muda adalah unsur pembantu pimpinan. Jaksa Agung Muda terdiri dari Jaksa Agung Muda Pembinaan; Jaksa Agung Muda 
Intelijen; Jaksa Agung Muda Tindak Pidana Umum; Jaksa Agung Muda

Tindak Pidana Khusus; Jaksa Agung Muda Perdata dan Tata Usaha Negara; Jaksa Agung Muda Pengawasan.

\section{G. Simpulan}

Berdasarkan pasal 22 Undang Undang No 16 Tahun 2004 dapat disimpulkan bahwa kedudukan Jaksa Agung tidak independen.Hal ini disebabkan Jaksa Agung diangkat dan diberhentikan oleh Presiden. Kejaksaan selaku institusi penegak hukum seharusnya di tempatkan pada lembaga yudikatif, akan tetapi dalam praktiknya Kejaksaan ditempatkan pada ranah eksekutif.Terdapat keterkaitan yang jelas antara kedudukan lembaga Kejaksaan dengan kemandirian lembaga kejaksaan itu sendiri.

Lembaga Kejaksaan yang mantap kedudukannya dan telah memiliki kemandirian seharusnya lepas dari eksekutif. Perlu diadakan reposisi terhadap Lembaga Kejaksaan Indonesia, dimana harus benar-benar terpisah dari badan eksekutif dan termasuk kedalam kekuasaan yudikatif (kekuasaan kehakiman).Harus dibentuk lembaga tersendiri berupa Kejaksaan Republik Indonesia yang kedudukannya diteguhkan dalam konstitusi termasuk dalam hal ini menyangkut masalah kemandirian seperti halnya Mahkamah Agung atau kembali memasukkan Kejaksaan dalam Mahkamah Agung, sehingga kedudukannya sudah terjamin dalam konstitusi karena termasuk dalam Kekuasaan Kehakiman. Di dalam pemilihan Jaksa Agung sebaiknya melibatkan Dewan Perwakilan Rakyat sebagai representasi dari Rakyat Indonesia Dihapuskannya tanggungjawab hierarkis, dimana seorang Jaksa dalam melakukan penuntutan dapat dilakukan secara mandiri, seperti halnya hakim dan kepolisian. 


\section{Daftar Pustaka}

Asshiddiqie Jimly, Konstitusi Dan Konstitusionalisme Indonesia, Jakarta: Konstitusi Press, 2005.

Budiardjo Miriam, Dasar-dasar Ilmu Politik, Jakarta: Gramedia Pustaka Utama, 2001.

Daliyo J.B, Pengantar Hukum Indonesia. Jakarta: PT Prenhallindo, 2001.

Huda Nimatul, Diktat bahan kuliah Hukum Tata Negara Indonesia, Yogyakarta: FH UII, 2005.

Kansil CST, Hukum Tata Pemerintahan Indonesia, Jakarta: Ghalia Indonesia, 1984.

Magnis Suseno Frans, Etika Politik, Jakarta: Gramedia, 2001.

Suny Ismail, Mencari Keadilan, Bandung: Ghalia Indah, 1982.

Wahyono Padmo, Negara Hukum Republik Indonesia, Jakarta: Rajawali, 1982. 